\title{
Population structure of Liparis loeselii (L.) Rich. in relation to habitat conditions in the Warta River valley (Poland)
}

\author{
Agnieszka Błońska ${ }^{1}$, Dariusz Halabowski² \& Agnieszka Sowa ${ }^{2}$
}

${ }^{1}$ Department of Botany and Nature Protection, University of Silesia, Jagiellońska 28, 40-032 Katowice, Poland

${ }^{2}$ Department of Hydrobiology, University of Silesia, Bankowa 9, 40-007 Katowice, Poland

* corresponding author (e-mail: agnieszka.blonska@us.edu.pl)

\begin{abstract}
The paper presents results of a study on the population structure of the orchid Liparis loeselii growing in the Warta River valley peat bog in Myszków (Woźnicko-Wieluńska Upland, S. Poland). Individuals of L. loeselii occurred in patches of Menyantho trifoliatae-Sphagnetum teretis and Eleocharitetum pauciflorae - associations. The demographic structure of $L$. loeselii populations was described by variations in plant height, the length and width of leaves and the number of flowers of the constituting individuals. It was observed that habitat conditions such as conductivity, $\mathrm{pH}$ and the percentage cover of tall perennials had the strongest effect on the structure of L. loeselii populations.
\end{abstract}

Key words: orchid, meta-population, rare species, fen, ecological site "Przygiełka" in Myszków

\section{Introduction}

Human activity causes habitat fragmentation and a decrease in the habitat area. This, in turn, causes a decrease in population abundance (Eriksson 1996). Small isolated populations are more vulnerable to extinction because of low genetic diversity (Oostermeijer et al. 2003). Peat bogs and wetland areas, on the one hand, are European habitats which undergo changes very quickly but, on the other hand, in peat bogs and wetland habitats many rare and endangered species may occur. Proper management and nature protection of rare and endangered species is possible only if their ecology, demography and genetics is well known and their processes are well understood (Oostermeijer et al. 2003). Currently, there is still a great deal that needs to be studied. Our knowledge and understanding of processes regarding population dynamics enables assessment and prediction of the number of individuals in the population of plant communities (Eriksson 1996). Studies of rare species demography provide important data about critical life stages and calculation of population growth rates (Harvey 1985; Crone et al. 2011). Relevant data influencing protection effectiveness are also provided by research conducted on, for example, relative proportions of individuals in different ontogenetic stages of their life cycle (Oostermeijer et al. 1994). In this study, the research focuses on Liparis loeselii (L.) Rich., a small orchid, which occurs in Europe and North America. This orchid remains the only representative of the Liparis genus in Poland and also in whole of Europe. The number of its individuals is declining in its overall distribution in Europe, including in Poland (Kucharski 2014; Oostermeijer \& Hartman 2014). Approximately, 300 localities of the species were recorded in Poland. Unfortunately, according to Kucharski (2014), half of the recorded localities no longer exist. L. loeselii has been given "endangered" species status in Central Europe (EN category) (Schnittler \& Günther 1999), while in Poland, this species has been placed in the Polish Red Book of Plants in the category "vulnerable species" (VU) (Kucharski 2014), and on the "Polish Red List", it has been placed in category E, i.e. critically endangered (Zarzycki \& Szelag 2006). In the Silesian Province, $L$. loeselii is considered to be endangered (EN) (Parusel \& Urbisz 2012). This orchid species is 
also protected by Polish Law (Regulation 2014) as well as by International Law, the Berne Convention (1979) and Council Directive (1992). Some L. loeselii populations growing in Poland are part of a national monitoring system (Kucharski 2010). Demographic monitoring conducted on the L. loeselii populations in the United Kingdom, on dune slack complexes (Jones 1998) and a fen (Wheeler et al. 1998) indicates that populations of this orchid are short-lived and rapidly expanding or disappearing as changes in site conditions take place (Jones 1998).

Due to high vulnerability of $L$. leoselii both in Poland and Europe, there is lack of data about conditions in which the species occurs as well as data about the population structure of this species. This study was undertaken in order to gather information on these population aspects in order to enable proper management and protection of this species.

The natural transition mire "Przygiełka" in Myszków has the largest population of $L$. loeselii on a natural bog in the Silesian Province (Halabowski \& Błońska 2015). This locality of $L$. loeselii became seriously endangered in 2014, and, therefore, it was decided to conduct this study there with the aim of characterizing the population at the newly found location.

This paper presents a spectrum of phytocoenoses and habitats in which L. loeselii occurs, and attempts to determine the impact of different habitat conditions on the population structure of the species in the Warta River valley. The conservation status of this particular population of the species is also assessed.

\section{Material and methods}

\subsection{Study species}

Liparis loeselii (L.) Rich. is a small, heliophilous perennial plant of the Orchidaceae family with an erect, straight and triangular stem (Kłosowski \& Kłosowski 2006). The inflorescence bears small, inconspicuous flowers producing fruit in the form of an elevated bag. Two leaves usually grow from pseudobulbs (Szlachetko 2001). It is a geophyte (Zarzycki et al. 2002), in the early stages of development entirely dependent on mycorrhizal fungi; however, adults can sometimes be fully autotrophic (Procházka \& Velísek 1983; Pawlikowski 2004). This orchid is a weak competitor, has CSR life strategy, and generative propagation predominates over vegetative. Flowers usually are self-pollinated, and only occasionally small wasps fly to them (Zarzycki et al. 2002; Pawlikowski 2004), but it is not clear up to now if wasps are passive or active visitors. In Poland, Liparis loeselii is recognized as a species occurring with high fidelity in plant communities representing the Caricion davallianae alliance and locally the Orchido-
Schoenetum nigricantis association (Głazek 1992; Matuszkiewicz 2008). Liparis loeselii (L.) Rich. most often occurs on bogs rich in calcium carbonate (Pawlikowski 2004), rarely in transitional mires, short sedge acid fen wet meadows on sandy soils and in Cladietum marisci phytocoenoses (Piękoś-Mirkowa \& Mirek 2003). It often occurs in anthropogenic habitats such as quarries, gravel and sand pits (Czylok \& Rahmonov 1996; Czylok 1997; Dubiel \& Gawroński 1998; Bzdon \& Ciosek 2006; Pisarczyk 2006; Bzdon 2009; Błońska 2010; Molenda et al. 2012). In the region of Silesia, the species occurs most frequently in habitats created as a result of human activity, mainly on wetlands developing on old, currently unexploited sand pits, in areas with discharge of mineral-rich groundwater that infiltrated through the Triassic rock (Czylok 1997; Błońska 2010; Molenda et al. 2012). In the Silesian Province, it rarely occurs in natural peat bogs, and only forms small populations (Olesiński \& Sendek 1980; Bernacki \& Nowak 1994; Nowak 1999; Pisarczyk 2006; Błońska 2013).

\subsection{Study area}

The study was conducted in July 2014 in Myszków, on the transition mire located in the valley of the Warta River in northern part of the town (N 50 35' 21", E $19^{\circ} 17^{\prime} 24^{\prime \prime}$ (Fig. 1). This bog has been subject to legal protection as an ecological site "Przygiełka" since 2002 (Regulation 2002). It is located in the WoźnickoWieluńska Upland (Kondracki 2011). The upland is composed of Mesozoic (Triassic and Jurassic) rocks

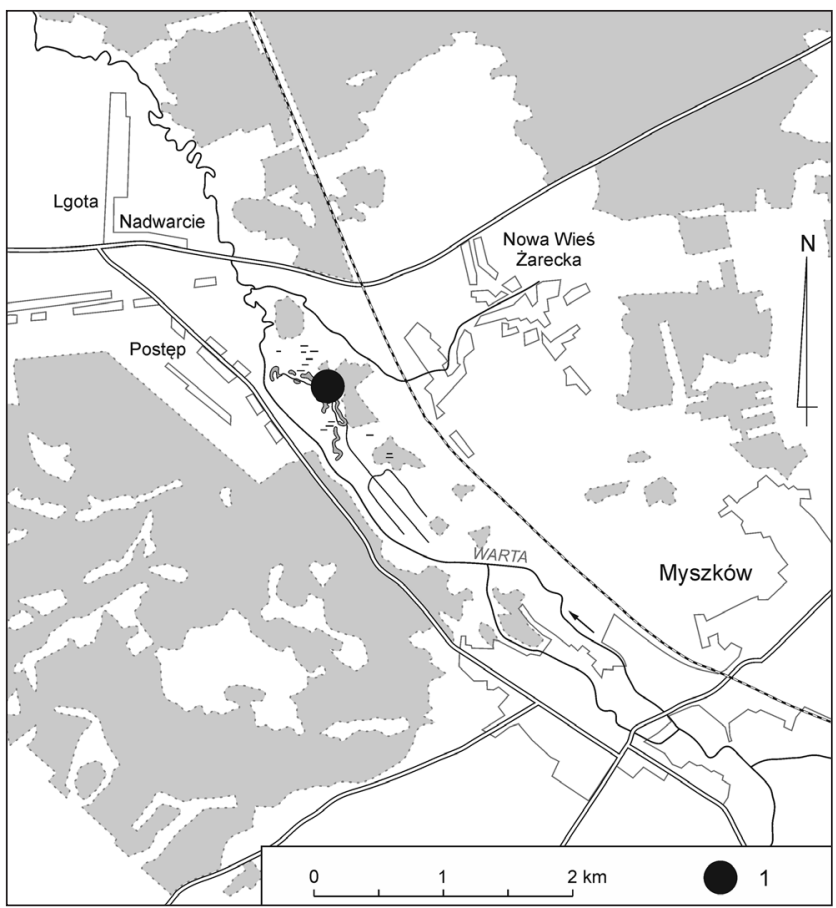

Fig. 1. Location of the studied population of Liparis loeselii in the ecological site "Przygiełka" in the Warta River valley in Poland 
consisting of limestone, sandstone, marl and clay. Lowering of the Upper Warta was established in little resistant ore-bearing clays of Middle Jurassic age. In the Quaternary, sands and glacial clay of varying thickness were deposited on clays (Dulias \& Hibszer 2004). In the Warta valley and its affluents, peat soils, created under anaerobic conditions with large amounts of water and high accumulation of organic matter occur. Among them, there are muck-mineral, silty-peat and peat soils with maximum thickness of up to $4 \mathrm{~m}$, with peatland vegetation, mainly transient (Myga-Piątek et al. 2003). The average annual rainfall reaches here $700-750 \mathrm{~mm}$ (Gil 2007). The average annual temperature ranges from 7.5- $8^{\circ} \mathrm{C}$ (Miroszewski et al. 2010).

\subsection{Field and laboratory studies}

In vegetation patches of $16 \mathrm{~m}^{2}$ area, lists of plant species occurring together with fen orchids were recorded. All species cover was evaluated in the modified 13-point Braun Blanquet scale (Chmura 2014). Vegetation relevés were arranged in a phytosociological table. The syntaxonomic status of the species was adopted from Matuszkiewicz (2008) and Ratyńska et al. (2010), the names of vascular plants follow Mirek et al. (2002), and of mosses (Ochyra et al. 2003).

Population and habitat studies were carried out in smaller plots with an area of $4 \mathrm{~m}^{2}$. Altogether, nine randomly distributed sample plots were set up in the area covering the entire Liparis population distribution on the peat bog "Przygiełka" in Myszków. From each recorded plot, water samples for further analyses of physico-chemical properties were collected. Electrical conductivity $\left[\mu \mathrm{S}^{*} \mathrm{~cm}^{-1}\right], \mathrm{pH}$, redox potential $[\mathrm{mV}]$, dissolved oxygen [\%], concentration of minerals and nitrogen in the form of nitrate ions $\left[\mathrm{mg}^{*} \mathrm{dm}^{-3}\right]$ were directly analyzed using the multi-parameter analyzer Professional Plus of YSI. Analyses of calcium, magnesium, sulfate and phosphate concentrations $\left[\mathrm{mg}^{*} \mathrm{dm}^{-3}\right]$ were performed with a spectrophotometer (DR 5000 Hach Lange). For each sample plot, environmental factors were determined as they might influence occurrence and parameters of Liparis individuals according to the methodology of national monitoring system (Kucharski 2010). The analyzed vegetation traits included: height of the herb layer [cm], a place to germinate [\%] (e.g. $\%$ of gaps not covered by plants and mosses), thickness of organic matter (mean from 20 measurements [cm]), habitat water content (defined in 5-point scale, where 1 means desiccated habitat and 5 water stagnant on the surface); separately cover by tall herbaceous perennial plants [\%] (e.g. cover of herbaceous plants that could cause shadow to $L$. loeselii individuals), shrub cover [\%] (e.g. cover of shrub and trees), herb cover layer [\%], moss cover layer [\%]. We only included environmental factors that are also used in the national plant species monitoring scheme (Kucharski 2010).

In addition, L. loeselii individuals were counted in sample plots, specifying whether they were generative, vegetative or juvenile. The recognition of age structure makes it possible to determine population structure (Kucharski 2010). We also measured morphological features of a series of Liparis individuals using an electronic caliper with an accuracy of $0.1 \mathrm{~mm}$. We performed the following six measurements on 70 flowering individuals: - plant height [mm], - length of the largest leaf [mm], - width of the largest leaf [mm], - inflorescence length $[\mathrm{mm}],-$ number of flowers, and - number of fruits.

The fruit set was also calculated, defining it as the percentage of flowers that developed ripe fruit. All morphological measurements were performed nondestructively, due to the fact that $L$. loeselii is legally protected (Regulation 2014).

Moreover, an assessment of habitat and population state was conducted, based on guidelines for species monitoring (Kucharski 2010).

\subsection{Numerical and statistical analysis}

Variability analysis was performed on the basis of morphological features of flowering plants. Variability of environmental factors was also analyzed. For each analyzed trait, basic statistics were provided: average, standard deviation, minimum and maximum. The calculations were conducted using Statistica 10. A Principal Component Analysis (PCA) was applied in order to show which features of plants were responsible for the diversity of Liparis individuals. In order to show the impact of environmental variables on the characteristics of individuals, CCA analysis was performed (Canonical Correspondence Analysis). Moreover, a Monte Carlo permutation test was performed. These analyses were performed with the assistance of CANOCO 4.5 software (ter Braak \& Šmilauer 2002).

\section{Results}

\subsection{Phytocoenotic spectrum}

Individuals of $L$. loeselii occurred in patches of Menyantho trifoliatae-Sphagnetum teretis and Eleocharitetum pauciflorae association (Table 1). These patches were quite rich in species (27-42 plant species). Herb and moss layer was well-formed in both types of phytocoenoses. The main constituents of these phytocoenoses were calciphilous species, character species of the Caricetalia davallianae order, as well as Scheuchzerio-Caricetea nigrae class. Physiognomy of the Menyantho trifoliatae-Sphagnetum teretis phytocoenoses was formed by massively occurring Menyanthes trifoliata, and Eleocharis quinqueflora 
Table 1. Floristic composition and structure of phytcoenoses with the participation of Liparis loeselii in Myszków

\begin{tabular}{|c|c|c|c|c|c|c|c|c|c|c|c|}
\hline Relevé identification number & 1 & 2 & 3 & 4 & 5 & 6 & 7 & 8 & 9 & & \\
\hline Field ID no. of relevé & 23 & 22 & 1 & 123 & 2 & 1 & 21 & 124 & 18 & & \\
\hline Cover shrub layer[\%] & 10 & 10 & 5 & 20 & 40 & - & 5 & 5 & 10 & & \\
\hline Cover herb layer [\%] & 100 & 100 & 90 & 90 & 90 & 80 & 90 & 90 & 80 & $\overline{0}$ & 7 \\
\hline Cover moss layer [\%] & 80 & 80 & 30 & 60 & 80 & 30 & 80 & 70 & 80 & & 急 \\
\hline Area of relevé $\left[\mathrm{m}^{2}\right]$ & 16 & 16 & 16 & 16 & 16 & 16 & 16 & 16 & 16 & 过 & ¿ \\
\hline Number of vascular plants in relevé & 35 & 31 & 21 & 24 & 31 & 27 & 35 & 35 & 28 & $\vec{g}$ & $\overline{0}$ \\
\hline Number of mosses in relevé & 6 & 7 & 6 & 5 & 6 & 9 & 7 & 5 & 5 & 空 & e \\
\hline Number of all species in phytosociological relevé & 41 & 38 & 27 & 29 & 37 & 36 & 42 & 40 & 33 & & \\
\hline
\end{tabular}

\begin{tabular}{cccccccccc} 
Number of all species in phytosociological relevé & 41 & 38 & 27 & 29 & 37 & 36 & 42 & 40 & 33 \\
\hline
\end{tabular}

\begin{tabular}{|c|c|c|c|c|c|c|c|c|c|c|c|c|}
\hline \multicolumn{2}{|c|}{ Plant community } & \multicolumn{5}{|c|}{$\begin{array}{c}\text { Menyantho trifoliatae- } \\
\text { Sphagnetum teretis }\end{array}$} & \multicolumn{4}{|c|}{$\begin{array}{c}\text { Eleocharitetum } \\
\text { pauciflorae }\end{array}$} & \multirow[b]{2}{*}{100} & \multirow[b]{2}{*}{133} \\
\hline *Liparis loeselii & c & 1 & 2 & 1 & 2 & 1 & 1 & 2 & 1 & 1 & & \\
\hline \multicolumn{13}{|c|}{ Ch. Scheuchzerio-Caricetea nigrae, *Caricetalia davallianae } \\
\hline Menyanthes trifoliata & $\mathrm{c}$ & 60 & 50 & 80 & 40 & 90 & 5 & 10 & 10 & 20 & 100 & 4056 \\
\hline Eriophorum angustifolium & $\mathrm{c}$ & 10 & 10 & 10 & 40 & 10 & & 5 & 2 & 2 & 89 & 1113 \\
\hline Carex nigra & $\mathrm{c}$ & 10 & 10 & 10 & 20 & 2 & & 5 & 20 & 10 & 89 & 1088 \\
\hline Comarum palustre & $\mathrm{c}$ & 2 & 10 & 10 & 20 & 5 & 5 & 10 & 5 & 5 & 100 & 800 \\
\hline Hydrocotyle vulgaris & $\mathrm{c}$ & 1 & & 1 & 2 & 5 & 10 & 5 & 5 & 5 & 89 & 425 \\
\hline Juncus articulatus & c & 2 & 2 & 1 & 2 & 2 & & 2 & 2 & 2 & 89 & 188 \\
\hline *Eleocharis quinqueflora & $\mathrm{c}$ & 10 & & & & 1 & 80 & 40 & 50 & 20 & 67 & 3350 \\
\hline Agrostis canina & $\mathrm{c}$ & 1 & & 1 & & & 2 & 1 & 5 & 5 & 67 & 250 \\
\hline Triglochin palustre & $\mathrm{c}$ & & & & & & 10 & 10 & 2 & 5 & 44 & 675 \\
\hline *Valeriana simplicifolia & $\mathrm{c}$ & 1 & 1 & & 5 & & 2 & 2 & & & 56 & 220 \\
\hline Viola palustris & $\mathrm{c}$ & 1 & & 2 & & & & 1 & 5 & 1 & 56 & 200 \\
\hline *Epipactis palustris & $\mathrm{c}$ & 2 & 2 & & & & & 1 & & 1 & 44 & 150 \\
\hline Carex diandra & $\mathrm{c}$ & & & 30 & & & & 20 & & 2 & 33 & 1733 \\
\hline Rhynchospora alba & $\mathrm{c}$ & & 10 & & & & & & 5 & 2 & 33 & 567 \\
\hline *Carex lepidocarpa & $\mathrm{c}$ & 1 & 2 & & & 5 & & & & & 33 & 267 \\
\hline *Carex flava & $\mathrm{c}$ & 2 & & & & & 2 & & 1 & & 33 & 167 \\
\hline *Carex pulicaris & $\mathrm{c}$ & & & & & 5 & & & & & 11 & 500 \\
\hline *Carex davalliana & $\mathrm{c}$ & & 2 & & & & & & 5 & & 22 & 350 \\
\hline Drosera anglica & $\mathrm{c}$ & 1 & & & & & & & & & 11 & 100 \\
\hline *Carex dioica & $\mathrm{c}$ & & & & & 1 & & & & & 11 & 100 \\
\hline Sphagnum contortum & d & 20 & 20 & 5 & & 10 & 5 & 10 & 20 & 30 & 89 & 1500 \\
\hline *Scorpidium scorpioides & d & & & & & & 2 & & 5 & & 22 & 350 \\
\hline Sphagnum teres & d & 5 & & & & & 2 & & & & 22 & 350 \\
\hline Cinclidium stygium & d & 2 & 5 & & & & 2 & & & & 33 & 300 \\
\hline Hamatocaulis vernicosus & d & & 2 & 1 & 5 & 2 & & & & & 44 & 250 \\
\hline *Campylium stellatum & $d$ & & & & & & 1 & 2 & & & 22 & 150 \\
\hline \multicolumn{13}{|c|}{ Sporadic species: Carex echinata $8(5)$} \\
\hline \multicolumn{13}{|c|}{ Ch. Oxycocco-Sphagnetea } \\
\hline Oxycoccus palustris & $\mathrm{c}$ & & 20 & & 10 & 1 & 5 & 10 & 10 & 20 & 78 & 1086 \\
\hline Drosera rotundifolia & $\mathrm{c}$ & 1 & 1 & & & 1 & 1 & 1 & 2 & 1 & 78 & 114 \\
\hline Sphagnum fallax & d & & & & & 2 & 2 & 30 & 20 & 20 & 56 & 1480 \\
\hline Aulacomnium palustre & d & & 2 & & 5 & & & 5 & & & 33 & 400 \\
\hline \multicolumn{13}{|l|}{ Ch. Molinio-Arrhenatheretea } \\
\hline Galium uliginosum & $\mathrm{c}$ & 2 & 1 & 2 & 2 & 1 & 2 & 2 & 1 & 10 & 100 & 256 \\
\hline Lythrum salicaria & $\mathrm{c}$ & 1 & & 1 & 2 & 5 & 2 & 1 & 2 & & 78 & 200 \\
\hline Lysimachia vulgaris & $\mathrm{c}$ & 2 & 1 & & & 1 & & 5 & 1 & & 56 & 200 \\
\hline Carex hirta & $\mathrm{c}$ & & 5 & & & & & & & 5 & 22 & 500 \\
\hline Succisa pratensis & $\mathrm{c}$ & & & & 2 & & & 5 & & & 22 & 350 \\
\hline Molinia caerulea & $\mathrm{c}$ & & & & 2 & & 2 & & 2 & & 33 & 200 \\
\hline Cirsium palustre & $\mathrm{c}$ & & 1 & & & 1 & & 1 & & & 33 & 100 \\
\hline Prunella vulgaris & $\mathrm{c}$ & & & & & & 1 & & 1 & 1 & 33 & 100 \\
\hline Potentilla anserina & $\mathrm{c}$ & & 1 & & & & & 1 & & & 22 & 100 \\
\hline Sanguisorba officinalis & $\mathrm{c}$ & & & & & & 1 & & & 1 & 22 & 100 \\
\hline
\end{tabular}

Sporadic species: Equisetum palustre 3(2); Epilobium palustre 2(1); Filipendula ulmaria 5(1); Climacium dendroides $\mathrm{d} 3(2)$

\section{Ch. Phragmitetea}




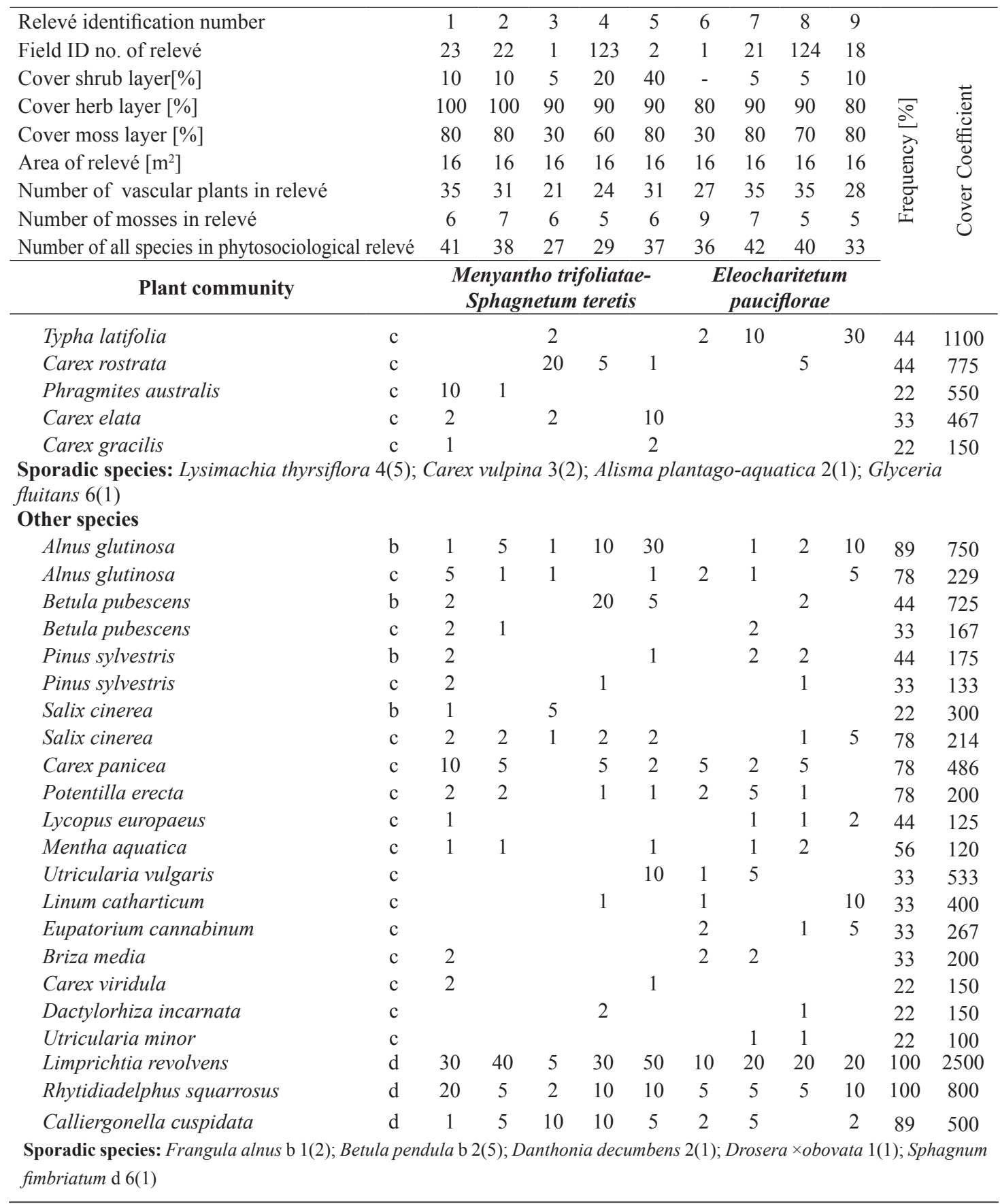

Explanations: date 24-25. 06. 2014; locality Ecological site "Przygiełka"; * - species from the Caricetalia davallianae order

occurred in Eloecharitetum pauciflorae patches with large coverage. In the studied patches, some species of more acidic habitat like Eriophorum angustifolium, Carex nigra or Oxycoccus palustris were also numerous. Apart from typical bog species, also species characteristic of other classes of vegetation, mainly of Molinio-Arrhenatheretea and Phragmitetea classes were recorded in the studied vegetation patches. Tall perennial species belonging to meadow vegetation reached high cover in some patches, directly shading the (micro)habitat of Liparis. Shrub and tree layers did not reach high coverage.

\subsection{Habitat spectrum}

L. loeselii occupied a relatively well hydrated habitat, where water was visible on the surface after low pressure. It was characterized by $\mathrm{pH}$ ranging from 6.5 to 6.96 and electrical conductivity from 161.5 to $400.9 \mu \mathrm{S}^{*} \mathrm{~cm}^{-1}$. Average calcium concentration was $28.37 \mathrm{mg}^{*} \mathrm{dm}^{-3}$, and magnesium ions $-7.06 \mathrm{mg}^{*} \mathrm{dm}^{-3}$. Water sampled from the Liparis habitat contained an average of $33.22 \mathrm{mg}^{*} \mathrm{dm}^{-3}$ of sulphate ions, while concentrations of nitrate $\left(5.94 \mathrm{mg}^{*} \mathrm{dm}^{-3}\right)$ and phosphate $\left(0.17 \mathrm{mg}^{*} \mathrm{dm}^{-3}\right)$ were relatively small (Table 2$)$. All the analyzed water properties showed high variability. 
Table 2. Characteristics of habitat of the Liparis loeselii study population

\begin{tabular}{|c|c|c|c|c|}
\hline Parameter & Minimum & Maximum & Mean & Standard deviation \\
\hline $\mathrm{pH}$ (median) & 6.50 & 6.96 & 6.62 & 0.14 \\
\hline Dissolved oxygen [\%] & 23.00 & 55.00 & 41.11 & 9.56 \\
\hline Electrical conductivity $\left[\mu \mathrm{S}^{*} \mathrm{~cm}^{-1}\right]$ & 161.50 & 400.90 & 244.51 & 68.79 \\
\hline Concentration of minerals $\left[\mathrm{mg}^{*} \mathrm{dm}^{-3}\right]$ & 105.30 & 260.65 & 158.44 & 45.06 \\
\hline Redox potential $[\mathrm{mV}]$ & 169.70 & 197.80 & 182.61 & 9.85 \\
\hline 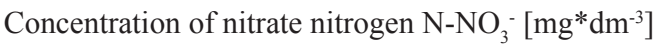 & 4.79 & 10.27 & 5.94 & 1.70 \\
\hline Concentration of calcium ions $\mathrm{Ca}^{2+}\left[\mathrm{mg}^{*} \mathrm{dm}^{-3}\right]$ & 11.60 & 43.70 & 28.37 & 9.39 \\
\hline Concentration of magnesium ions $\mathrm{Mg}^{2+}\left[\mathrm{mg}^{*} \mathrm{dm}^{-3}\right]$ & 0.80 & 13.40 & 7.06 & 5.04 \\
\hline Concentration of sulphates $\mathrm{SO}_{4}^{2-}\left[\mathrm{mg}^{*} \mathrm{dm}^{-3}\right]$ & 22.00 & 77.00 & 33.22 & 16.84 \\
\hline Concentration of phosphates $\mathrm{PO}_{4}^{3}-\left[\mathrm{mg}^{*} \mathrm{dm}^{-3}\right]$ & 0.06 & 0.45 & 0.17 & 0.11 \\
\hline Height of a herb layer $[\mathrm{cm}]$ & 30.00 & 50.00 & 37.78 & 8.33 \\
\hline Cover of tall perennial herbs $[\%]$ & 0.00 & 40.00 & 12.22 & 14.6 \\
\hline Cover of shrubs and trees [\%] & 0.00 & 40.00 & 15.83 & 14.29 \\
\hline Place to germinate/bare soil $[\%]$ & 0.00 & 20.00 & 11.11 & 7.41 \\
\hline Degree of hydration & 3.00 & 4.00 & 3.44 & 0.53 \\
\hline Leaf thickness $[\mathrm{cm}]$ & 0.00 & 2.00 & 1.11 & 1.05 \\
\hline Cover shrub layer $[\%]$ & 0.00 & 40.00 & 12.22 & 14.60 \\
\hline Cover herb layer [\%] & 60.00 & 90.00 & 75.56 & 13.33 \\
\hline Cover moss layer [\%] & 20.00 & 100.00 & 53.33 & 25.98 \\
\hline
\end{tabular}

L. leoselii individuals grew in places where average height of dense litter sward was nearly $40 \mathrm{~cm}$, tall perennials covered from 0 to $40 \%$ of the surface and shrubs about $15 \%$. Coverage of the herb layer was $60-90 \%$ and moss layer covered $20-100 \%$ of the area (Table 2 ).

\subsection{Morphological differentiation and population structure}

Flowering adult individuals reached an average height of almost $134 \mathrm{~mm}$, but the range of this trait was considerable (from 52.6 to $247.6 \mathrm{~mm}$ ). The length and width of the largest leaf were also highly variable, ranging between 35 and $207.7 \mathrm{~mm}$ and 11 and $36 \mathrm{~mm}$, respectively. The mean number of flowers per inflorescence was 8 , and ranged from 2 to 23 . The number of set fruits was significantly lower with averaged value of 2.56. That was the reason for a very small percentage of fruiting individuals, reaching an average of
$34 \%$, although there were individuals which did not effectively initiate establishing fruits, as well as those for which the success of fruiting reached 100\% (Table 3). L. loeselii individuals from Myszków showed relatively little variation in terms of metric traits (small gradient on the axes of PCA). The first two axes of the PCA explain $89 \%$ of the variance in the data set. The first axis accounted for more than $74 \%$ of the variance and was correlated with plant height, leaf length and width and the number of flowers. The second axis, explaining 15\% of the variance, was correlated with fruit set (Fig. 2).

In total, we counted 154 individuals in 9 plots, among them 111 vegetative and 37 generative, although the size of the entire population of fen orchid was estimated at more than 200 individuals, which occurred across the area of approx. $3000 \mathrm{~m}^{2}$. Calculations showed that $24 \%$ of individuals flowered (out of 154 analyzed). The number of juveniles and damaged individuals was negligible.

Table 3. Characteristics of Liparis loeselii individuals

\begin{tabular}{lcccc}
\hline \multicolumn{1}{c}{ Feature } & Minimum & Maximum & Mean & Standard deviation \\
\hline Plant height [mm] & 52.60 & 247.60 & 133.96 & 39.05 \\
Inflorescence length [mm] & 13.00 & 115.80 & 46.10 & 22.21 \\
Longest leaf length [mm] & 35.00 & 207.70 & 103.81 & 33.04 \\
Widest leaf width [mm] & 11.00 & 36.00 & 21.06 & 5.46 \\
Number of flowers & 2.00 & 23.00 & 8.07 & 4.09 \\
Number of fruits & 0.00 & 10.00 & 2.56 & 1.95 \\
Fruit set [\%] & 0.00 & 100.00 & 34.43 & 22.84 \\
\hline
\end{tabular}




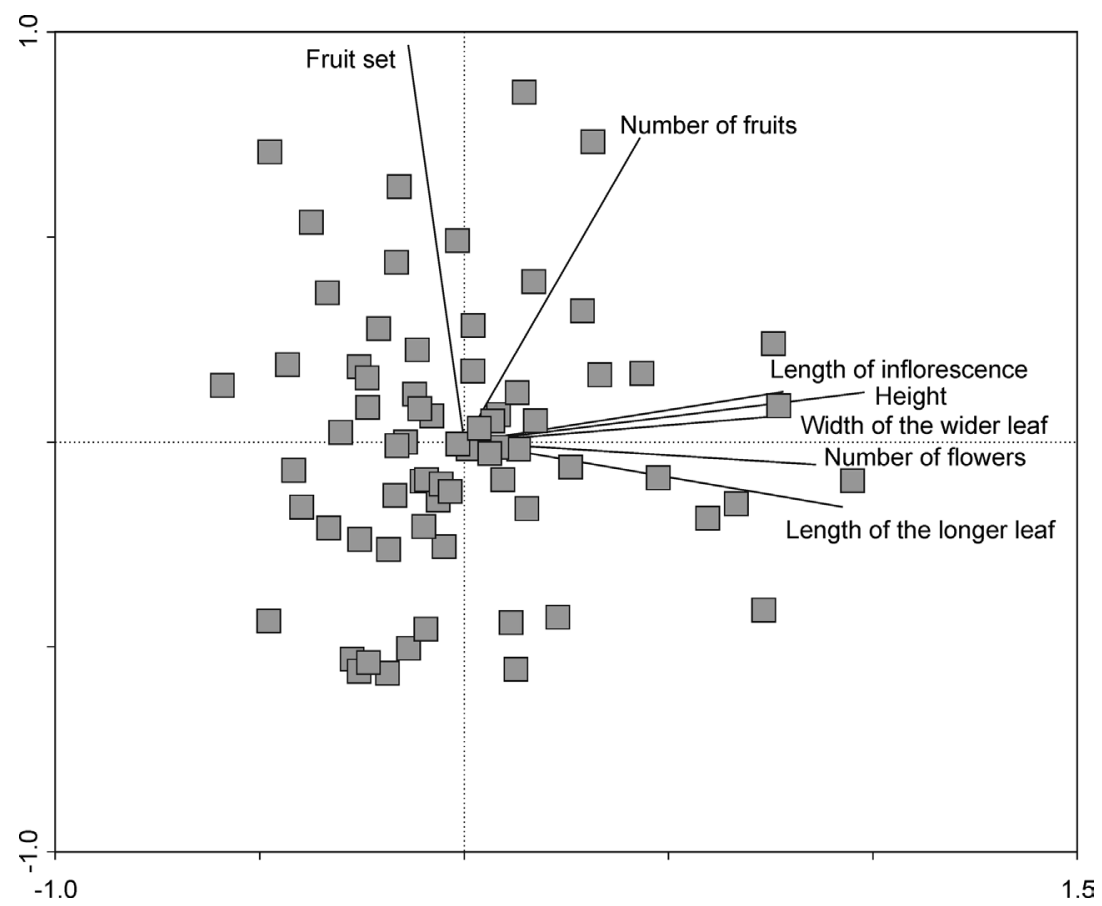

Fig. 2. Principal Component Analysis (PCA) of morphological measurements of Liparis loeselii individuals in the Warta river valley population in Poland

\subsection{Impact of environmental conditions on inter-individual characteristics}

Of the 19 analyzed environmental factors, 7 had a significant effect on individual characteristics of $L$. loeselii (Monte Carlo test). The most significant was electrical conductivity, which correlated negatively with fruiting success and positively with plant height and leaf length. The $\mathrm{pH}$ and overgrowing by tall perennial herbs significantly positively affected the number of flowers and inflorescence length (Fig. 3). The first two axes of the CCA explained more than $97 \%$ of relationships between traits and environmental conditions.

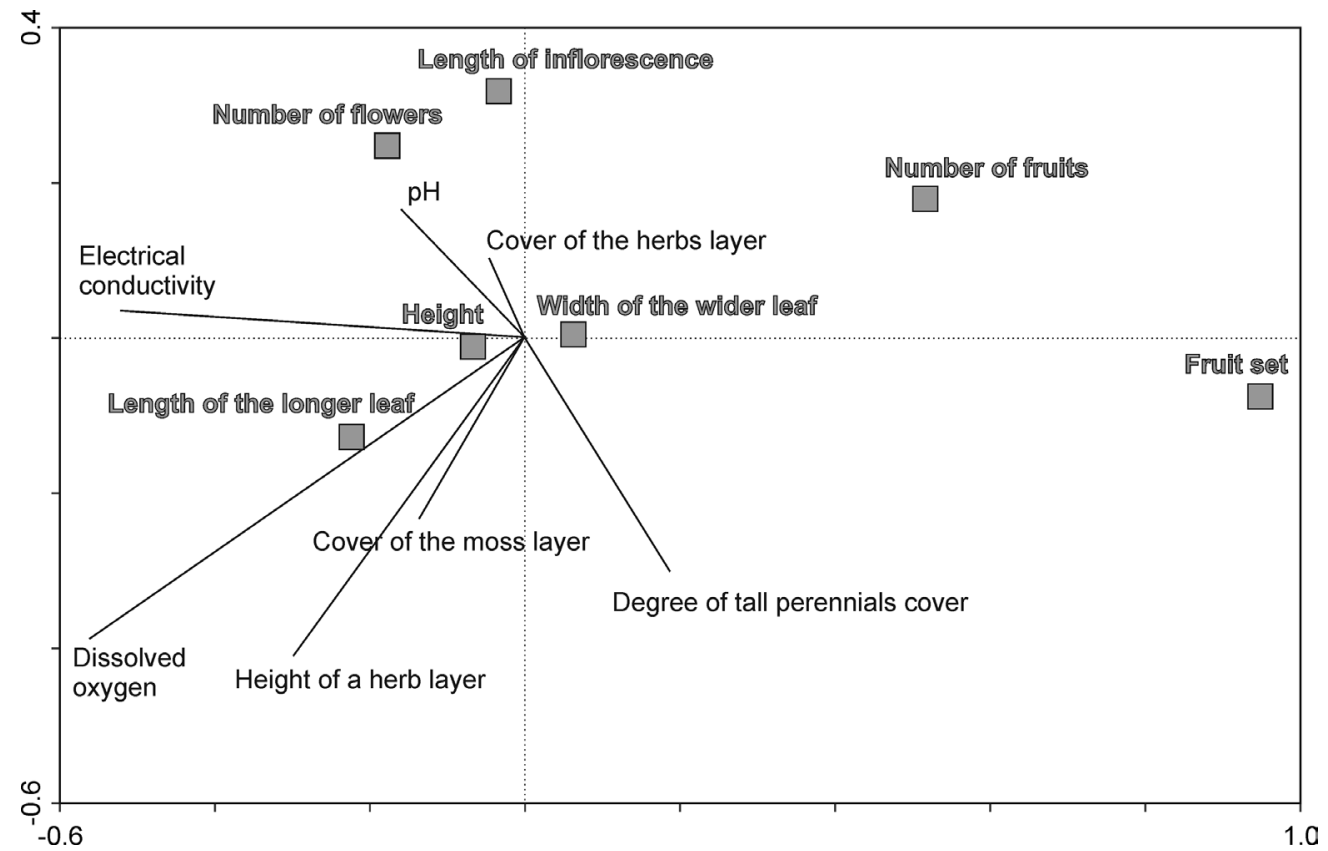

Fig. 3. Canonical Correspondence Analysis (CCA) showing the relationship between the characteristics and conditions of Liparis loeselii habitat in the Warta river valley in Poland 


\subsection{Evaluation of population status and habitat}

The number of $L$. loeselii individuals, presence of generative as well as health condition (no damaged or injured individuals) allowed to consider the state of the L. loeselii population on the "Przygiełka" ecological site as appropriate according to the requirements of the national monitoring of plant species. In contrast, the state of habitat of this species according to the criteria set out in the guidelines of the national monitoring of plant species was unsatisfactory. This was due to: sward height and relatively large coverage of high perennial and expansive species such as Phragmites australis, Typha latifolia, Eupatorium cannabinum and some species of tall sedges in some patches; all the listed species shaded the habitat of fen orchid. Among current possible negative impacts on the $L$. loeselii population and habitat, one should include: a gradual succession of vegetation and trampling by people visiting the place.

\section{Discussion}

Average values of all analyzed Liparis specimen traits from Myszków fell within typical ranges given in the keys for plant recognition and descriptions of the species (Szafer et al. 1988; Rutkowski 2011; Wheeler et al. 1998; Szlachetko 2001, Pawlikowski 2004; Kłosowski \& Kłosowski 2006; Oostermeijer \& Hartman 2014). However, they were much higher compared to the results obtained by Naczk \& Minasiewicz (2010) from Gdańsk Pomerania. This pattern applied to all analyzed traits with the exception of the success of fruiting. Although individuals of fen orchid from Myszków developed an average of nearly twice as many flowers compared to individuals from Gdańsk Pomerania (Naczk \& Minasiewicz 2010), they established fewer fruits and the studied individuals were nearly half as successful in fruiting than individuals described form other localities. The maximum values of all the measured parameters were higher than those reported in literature (Szafer et al. 1988; Rutkowski 2011; Wheeler et al. 1998; Szlachetko 2001; Pawlikowski 2004; Kłosowski \& Kłosowski 2006; Urban 2013; Oostermeijer \& Hartman 2014).

There is little data on what the habitat requirements of $L$. loeselii are. It is known that it most often grows on peat soils, with neutral or alkaline to only weakly acidic water reaction (6.6) 6.9-7.6 (7.8) (Pawlikowski 2004; Kucharski 2014). Habitat of fen orchid in Myszków does not differ from the one reported in the literature in terms of $\mathrm{pH}$. In terms of average values of $\mathrm{pH}$ and electrical conductivity, the analyzed habitat of $L$. loeselii did not differ from those of Poręba near Zawiercie (Błońska 2013), although the maximum value of the second parameter almost twice exceeded the value from Poręba. It was also similar to the habitat where L. loeselii occurred on moors in the Netherlands in terms of coverage of moss layer, a place where the orchid to germinate most likely and thickness of litter. Coverage of herb and shrubs layer, as well as $\mathrm{pH}$, were higher in Myszków than in the Netherlands (Oostermeijer \& Hartman 2014).

The analyzed population was dominated by generative adults. Demographic studies on L. loeselii show that generative adults have the best chance of emergence in the next season (McMaster 2001). They are the least susceptible to changeable environmental conditions. Wheeler et al. (1998) showed that the population stability of $L$. loeselii is possible, despite short life span and high mortality of juveniles, due to rapid development of the new generation from seeds. The possibility of renewal from seeds is crucial for the survival of this species. The population of fen orchid from Myszków had a relatively large proportion of generative individuals, but on the other hand, it showed signs of disorders associated with dominance of adults and a small share of juveniles, which might indicate difficulties in recruitment of seedlings and/or mortality of juveniles and problems with renewing of the population.

Information about how the habitat conditions affect the health of populations and fen orchid individuals is rare. It is known that $L$. loeselii is a heliophilous species (Pawlikowski 2004). It is also a typical species of early successional stages (Jones 1998; Wheeler et al. 1998), it grows most abundantly in habitats with sparse vegetation on moist calcareous soils, where, in natural conditions, there is no competition of tall herbaceous plants (McMaster 2001). The study of Jones \& Etherington (1992) showed that $L$. loeselii appeared between 12 and 15 years after initial vegetation establishment of the dune slacks.

The orchid started to decline when Salix repens shrub, developed a dense vegetation cover. Oostermeijer \& Hartman (2014) recorded L. loeselii on dunes and bogs, which were generally characterized by taller vegetation with higher cover than in initial habitats of dune slacks. These authors attributed $L$. loeselii occurrence to the fact that they occur on sites with higher open areas than in the dunes. Therefore, tall perennials, such as common reed (Phragmites australis) or bulrush (Typha latifolia) may threaten the population of $L$. loeselii individuals. In the studied site in Myszków, the $L$. loeselii population may be endangered because of a highly expansive reed expanding species into the peat bog vegetation. In addition, our results also showed a negative impact of perennial species abundance on the number of flowers in the fen orchid. It was shown that abiotic factors were also important and influenced survival and population density and other population features of this orchid. Oostermeijer \& Hartman (2014), studying bogs 
in the Netherlands, revealed that there was a positive correlation between the number of individuals and $\mathrm{pH}$ and negative correlations between the thickness of the litter layer and number of individuals. In our study, no statistically significant correlations with these habitat parameters were found (Spearman correlation, not shown). Water level is an important factor influencing the condition of individuals of $L$. loeselii. This species is dependent on good hydration of its habitat and a decline in hydration adversely affects leaf size (Roze et al. 2014). When changes in the water table, floods or dry periods are temporary, the species does not flower and survives in the vegetative stage. When the changes are permanent, however, the population may disappear after three or four years. In some studies, a reduction in the number of individuals was observed much earlier (Jersakova \& Kindlman 2004). Roze et al. (2014) reported the same observation. It is to be expected, therefore, that also in Myszków, any reduction in water level will be detrimental to the species. Recent dry and hot summers increase the likelihood of such events. As determined by the authors of the Report of the IPCC $(2007,2013)$, increasing temperature extremes and heavy rains may cause either dehydration or flooding of peat bogs. According to the climate model, heat waves as these recently observed are likely to become more frequent, longer and more intense (Kiktev et al. 2003; Meehl \& Tebaldi 2004; Beniston et al. 2007; Kürbis et al. 2009; Pongrácz et al. 2013).

Although the current status of fen orchid population in Myszków is satisfactory, it is necessary to conduct regular monitoring, both of the population as well as environmental conditions. The previous study showed that population life span of the species was very short, between 5 and 15 years and most of the population would disappear from the vegetation patch in the period between 4 and 8 years from its colonization (Eriksson 1996; Oostermeijer \& Hartman 2014). Research conducted by Oostermeijer \& Hartman (2014) suggests that L. loeselii must have highly dynamic meta-populations. According to the meta-populations theory, a species can exist as a system of groups of connected populations between different vegetation patches, habitats, fragments, so protection of species meta-populations should focus on keeping balance between colonization and extinction processes (Hanski 1999). The population genetic study conducted across Europe revealed that genetic differentiation between populations was generally low, and genetic variation within populations relatively high for a self-pollinating species (Pillon et al. 2007). These results suggest that a mechanism enabling dispersion among populations and habitat fragments must exist, e.g. multiplied foundation of a population. This might be possible due to a far distance dispersing system used by this orchid. The study conducted in the
Netherlands proved that colonisation and a new population can be founded in a long distance $(>25 \mathrm{~km})$. On Dutch Wadden islands, seed migration between islands almost $>100 \mathrm{~km}$ away was recorded (Pillon et al. 2007; Vanden Broeck et al. 2014).

In our study, the L. loeselii population closest to those growing in "Przygiełka" in Myszków was located in a protected area of Poręba near Zawiercie (Błońska 2013) which was about $15 \mathrm{~km}$ south. However, the Poręba population was low in species and it could hardly be a population source for the "Przygiełka" in Myszków L. loeselii locality. In the radius of $50 \mathrm{~km}$ from the "Przygiełka" in Myszków population, other 15 localities of L. loeselii were found (Błońska 2010) and this might be a population source for the "Przygiełka" in Myszków population. Among the above-mentioned 15 locations, the one located in Dąbrowa Górnicza (25 km away from Myszków) was probably initially the population source for our study object.

Such distance is not too far for orchid seeds to be dispersed, particular since the wind here blows mostly from the south supporting such dispersal.

The Dąbrowa Górnicza population developed in a primary habitat on an open cast sand pit which was left abandoned since the end of the $20^{\text {th }}$ century. This population is currently the richest in individuals in southern Poland. About several thousand L. loeselii individuals were recorded (Kucharski 2014). Taking all the above into consideration, the "Przygiełka" in Myszków population is not isolated, there are neighboring populations and potential habitats (e.g. the Warta valley and the Warta river tributary as well as other appropriate habitats often of anthropogenic origin) which might be colonized by $L$. loeselii individuals creating a population constituting part of the above-mentioned meta-population of the region.

However, because of short life span, fragmentation, changes of habitat patches and high rates of local extinction crucial for the meta-population survival is existence and/or creation of initial open habitats. Such open habitats might be created by peat removal enabling $L$. loeselii seeds to establish (Eriksson 1996; Oostermeijer et al. 2003, Oostermeijer \& Hartman 2014).

In order to protect $L$. loeselii meta-population, it is important to maintain the existing population as long as possible. This can be achieved on condition that the existing habitats are left unchanged which requires occasional mowing or removing shrubs and, definitely, leaving the hydrological conditions unchanged (Grootjans et al. 2002). Persistence of the L. loeselii population will depend on proper management of the area under consideration. This objective can be reached thanks to application of appropriate protection support tools and regular monitoring of the habitat conditions and population characteristics. 
Acknowledgements. We are grateful to the anonymous Reviewer for constructive comments to our manuscript. This work was financially supported by Ministry of Science and
Higher Education in years 2010-2013 (grant No. N N305 384938).

\section{References}

Beniston M., Stephenson D. B., Christensen O. B., Ferro C. A. T., Frei C., Goyette S., Halsnaes K., Holt T., Jylha K., Koffi B., Palutikof J., Scholl R., SemMLER T. \& Woth K. 2007. Future extreme events in European Climate: An exploration of regional climate model projections. Climatic Change 81: 81-95.

BERNACKi L. \& NowAK T. 1994. Materiały do rozmieszczenia i poznania zasobów chronionych gatunków roślin naczyniowych centralnej części Wyżyny ŚląskoKrakowskiej. Acta Biol. Siles. 25(42): 24-41.

Berne Convention 1979. Convention on the Conservation of European Wildlife and Natural Habitats. Bern, 19.09.1979. European Treaty Series 104.

BŁoŃSKA A. 2010. Siedliska antropogeniczne na Wyżynie Śląskiej jako miejsca występowania rzadkich i zagrożonych gatunków torfowiskowych klasy Scheuchzerio-Caricetea nigrae (North. 1937) R. Tx. 1937. Woda-Środowisko-Obszary Wiejskie 10(1): 7-19.

BŁońsKa A. 2013. Stanowisko Liparis loeselii (Orchidaceae) w Porębie koło Zawiercia (N kraniec Wyżyny Śląskiej). Fragm. Flor. Geobot. Polonica 20(1): 131158.

Bzdon G. \& Ciosek M. T. 2006. Fen orchid Liparis loeselii (L.) Rich. in abandoned gravel-pit in DąbrówkaStany near Siedlce (Poland). Biodiv. Res. Conserv. 1-2: 193-195.

BzDon G. 2009. Post-exploitation excavations as supplementary habitats for protected and rare vascular plant species. In: Z. MireK \& A. Nikiel (eds.). Rare, relict and endangered plants and fungi in Poland, pp. 137142. W. Szafer Institute of Botany, Polish Academy of Sciences, Kraków.

Chmura D. 2014. Charakterystyka fitocenotyczna leśnych zbiorowisk zastępczych z udziałem Quercus rubra L. na Wyżynie Śląskiej. Acta Botanica Silesiaca 10: 17-40.

Council Directive 92/43/EEC of 21 May 1992 on the Conservation of Natural Habitats and of Wild Fauna and Flora. Official Journal of European Communities OJ L 206, 22.7.1992

Crone E. E., Menges E. S., Ellis M., Bell T., Bierzychudek P., Ehrlén J., Kaye T. N., Knight T. M., Lesica P., Morris W. F., Oostermeijer J. G. B., QuintanaAscencio P. F., Stanley A., Ticktin T., Valverde T. \& Williams J. L. 2011. How do plant ecologists use matrix population models? Ecol. Lett. 14: 1-8.

Czylok A. \& Rahmanow O. 1996. Unikatowe układy fitocenotyczne w wyrobiskach wschodniej części województwa katowickiego. Kształtowanie środowiska geograficznego i ochrona przyrody na obszarach uprzemysłowionych i zurbanizowanych. 23: 27-31.
Czylok A. 1997. Pionierskie zbiorowiska ze skrzypem pstrym Equisetum variegatum Schlech. w wyrobiskach po eksploatacji piasku. In: S. WIKA (ed.). Roślinność obszarów piaszczystych, pp. 61-66. Wydział Biologii i Ochrony Środowiska Uniwersytet Śląski, Zespół Jurajskich Parków Krajobrazowych, Katowice-Dąbrowa Górnicza.

Dubiel E. \& GAwroński S. 1998. Osobliwości szaty roślinnej miasta i gminy Chrzanów. Chrońmy Przyr. Ojcz. 54(1): 5-15.

Dulias R. \& Hibszer A. 2004. Województwo śląskie. Przyroda, gospodarka, dziedzictwo kulturowe. 244 pp. Wydawnictwo Kubajak, Kraków.

ERIKSSON O. 1996. Regional dynamics of plants: a review of evidence for remnant, source-sink and metapopulations. Oikos 77: 248-258.

GIL R. 2007. Środowisko przyrodnicze w mieście Myszkowie. 18 pp. Biuletyn Informacji Publicznej, Myszków.

GŁAZEK T. 1992. Lipario-Schoenetum ferruginei - a new plant association. Fragm. Flor. Geobot. 37: 549-562.

Grootjans A. P., Geelen H. W. T., Jansen A. J. M. \& LamMERTS E. J. 2002. Restoration of coastal dune slacks in the Netherlands. Hydrobiol. 478, 181-203.

Halabowski D. \& BŁońska A. 2015. Obfite występowanie Liparis loeselii na Wyżynie Woźnicko-Wieluńskiej. Fragm. Flor. Geobot. Polonica 22(2): 12-16.

HANski I. 1999. Metapopulation Ecology. 324 pp. Oxford University Press, Oxford.

Harvey H. J. 1985. Population biology and the conservation of rare plant species. In: J. White (ed.). Studies on Plant Demography; a Festschrift for John L. Harper, pp. 111-123. Academic Press, London.

IPCC. 2007: Climate change: The physical science basis. Contribution of Working Group I to the Fourth Assessment Report of the Intergovernmental Panel in Climate Change. Cambridge University Press, Cambridge.

IPCC. 2013: Climate change: The physical science basis. Contribution of Working Group I to the Fifth Assessment Report of the Intergovernmental Panel in Climate Change. Cambridge University Press, Cambridge.

Jersakova J. \& KinNDLman P. 2004. Reproductive success and sex variation in nectarless and rewarding orchids. Int. J. Plant Sci. 165: 779-785.

Jones P. S. 1998. Aspects of the population biology of $\mathrm{Li}$ paris loeselii (L.) Rich. var. ovate Ridd. ex Godfery (Orchidaceae) in the dune slacks of South Wales. Bot J. Linn. Soc. 126: 123-139.

Jones P. S. \& Etherington J. R. 1992. Autoecological studies on the rare orchid L. loeselii and their application to the management of dune slack ecosystems in SouthWales. In: R. W. G. Carter, T. G. F. Curtis \& S. M. J. SHeEHy (eds.). Coastal dunes, geomorphology, eco- 
logy and management for conservation, pp. 299-312. Balkema, Rotterdam.

Kiktev D., Sexton D. M. H., Alexander L. \& Folland C. K. 2003. Comparison of modeled and observed trends in indices of daily climate extremes. Journal of Climate 16: 3560-3571.

KŁosowski S. \& KŁosowski G. 2006. Flora Polski. Rośliny wodne i bagienne. 333 pp. Multico Oficyna Wydawnicza, Warszawa.

Kondracki J. 2011. Geografia regionalna Polski. 440 pp. Wyd. Nauk. PWN, Warszawa.

KuChARSKi L. 2010. Lipiennik Loesela Liparis loeselii (L.) Rich. In: J. Perzanowska (ed.). Monitoring gatunków roślin. Przewodnik metodyczny, pp. 99-109. Biblioteka monitoringu środowiska, Warszawa.

Kucharski L. 2014. Liparis loeselii (L.) Rich. In. R. Kaźmierczakowa, K. Zarzycki \& Z. Mirek (eds.). Polska Czerwona Księga Roślin. Paprotniki i rośliny kwiatowe, pp. 793-795. Instytut Botaniki im. W. Szafera PAN, Kraków.

Kürbis K., Mudelsee M., Tetzlaff G. \& Brázdil R. 2009. Trends in extremes of temperature, dew point, and precipitation from long instrumental series from Central Europe. Theoretical and Applied Climatology 98: 187-195.

Matuszkiewicz W. 2008. Przewodnik do oznaczania zbiorowisk roślinnych Polski. In: J. B. Faliński (ed.). Vademecum Geobotanicum 3, 537 pp. Wyd. Nauk. PWN, Warszawa.

MCMAster R. T. 2001. The population biology of Liparis loeselii, Loesel'stwayblade, in a Massachusetts wetland. Northest. Nat. 8 (2): 163-178.

Meenl G. A. \& Tebaldi C. 2004: More intense, more frequent, and longer lasting heat waves in the 21 st century. Science 305: 994-997.

Mirek Z., Piękoś-Mirkowa H., Zając A. \& ZająC M. 2002. Flowering plants and pteridophytes of Poland. A checklist. In: Z. MireK (ed.). Biodiversity of Poland, 1, 442 pp. W. Szafer Institute of Botany, Polish Academy of Sciences, Kraków.

Miroszewski K., Durka J., Nita M. \& ZwiązeK J. 2010. Po obu stronach Warty: zarys dziejów Myszkowa. 686 pp. Urząd Miasta Myszków, Myszków.

Molenda T., BŁońska A. \& Chmura D. 2012. Charakterystyka hydrogeniczno-hydrochemiczna antropogenicznych mokradeł (na przykładzie obiektów w starych piaskowniach). Inżynieria Ekologiczna 29: 110-118.

Myga-Piątek U., Nita J., Absalon D., Stebel A., Leśniok M. \& BIAŁEK B. 2003. Wartości przyrodnicze i kulturowe miasta Myszkowa. 133 pp. Wydawnictwo Urzędu Miasta Myszkowa, Myszków.

NACZK A. \& MinASIEWICZ J. 2010. Zróżnicowanie morfologiczne i ekologiczne wybranych populacji Liparis loeselii (L.) L. C. Rich. (Orchidaceae) na Pomorzu Gdańskim. Acta Bot. Cassub. 7-9: 147-160.

NowaK T. 1999. Atlas rozmieszczenia roślin naczyniowych na terenie wschodniej części Garbu Tarnogórskiego (Wyżyna Śląska). Centrum Dziedzictwa Przyrody Górnego Śląska. Materiały i opracowania 2: 1-103.

Ochyra R., Żarnowiec J. \& Bednarek-Ochyra H. 2003. Census Catalogue of Polish Mosses. In: Z. Mirek (ed.).
Biodiversity of Poland, 3, 372 pp. Polish Academy of Sciences, Institute of Botany, Kraków.

OlesińsKi L. \& SENDEK A. 1980. Rhynchosporetum albae Koch koło Dąbrowy Górniczej na Wyżynie Śląskiej. Fragm. Flor. Geobot. 26(2-4): 315-319.

Oostermeijer J. G. B. \& Hartman Y. 2014. Inferring population and metapopulation dynamics of Liparis loeselii from single-census and inventory data. Acta Oecologica 60: 30-39.

Oostermeijer J. G. B., Luijten S. H. \& den Nijs J. C. M. 2003. Integrating demographic and genetic approaches in plant conservation. Biol. Conserv. 113: 389-398.

Oostermeijer J. G. B., van't Veer R. \& den Nijs J. C. M. 1994. Population structure of the rare, long-lived perennial Gentiana pneumonanthe in relation to vegetation and management in The Netherlands. J. Appl. Ecol. 31: 428-438.

Parusel J. B. \& Urbisz A. (eds.). 2012. Czerwona lista roślin naczyniowych województwa śląskiego. Raporty Opinie 6(2): 105-177.

Pawlikowski P. 2004. Liparis loeselii (L.) Rich. Lipiennik Loesela. In: B. Sudnik-WóJcikowska\& H. WerblanJAKUBIEC (eds.). Gatunki roślin. Poradnik ochrony siedlisk i gatunków. Natura 2000 - poradnik metodyczny, 9, pp. 150-154. Ministerstwo Środowiska, Warszawa.

Pięroś-Mirkowa H. \& Mirek Z. 2003. Flora Polski. Atlas roślin chronionych. 584 pp. Multico Oficyna Wydawnicza, Warszawa.

Pillon Y., Qamaruz-Zaman F., Fay M. F., Hendoux F. \& PiQuot Y. 2007. Genetic diversity and ecological differentiation in the endangered fen orchid (Liparis loeselii). Conserv. Genet. 8: 177-184.

PisARCZyk E. 2006. Nowe stanowisko lipiennika Loesela (L.) Rich. na terenie Krakowa na tle rozmieszczenia gatunku w południowo-wschodniej Polsce. Chrońmy Przyr. Ojcz. 62(5): 40-54.

Pongrácz R., Bartholy J. \& Bartha E. B. 2013. Analysis of projected changes in the occurrence of heat waves in Hungary. Advances in Geosciences 35: 115-122.

ProcházKa F. \& VeliseK V. 1983. Orchidejen aši přirody. 279 pp. Českoslov. Acad. VED, Praha.

RatyŃska H., Wojterska M. \& Brzeg A. 2010. Multimedialna encyklopedia zbiorowisk roślinnych Polski ver. 1.1. Instytut Edukacyjnych Technologii Informatycznych.

Roze D., Jakobsone G., Megre D., Belogrudova I. \& KarLOVSKA A. 2014. Survival of Liparis loeselii (L.) as an early successional species in Engure region described based on ecological peculiarities during the annual cycle. In: Proceedings of the Latvian Academy of Sciences. Section B. Natural, Exact, and Applied Sciences 68(1-2): 93-100.

Regulation 2002. Rozporządzenie nr 8/2002 Wojewody Śląskiego z dnia 28 lutego 2002 r. w sprawie uznania za użytek ekologiczny torfowiska przejściowego pod nazwą „Przygiełka” w gminie Myszków (Dz. Urz. Woj. Śl. Nr 17/02, poz. 528).

REGULATION 2014. Regulation of Minister of Environment of 9 October 2014 on plant species protection. Journal of Laws 2014 item 1409. 
RUTKOwSKi L. 2011. Klucz do oznaczania roślin naczyniowych Polski niżowej. 812 pp. Wyd. Nauk. PWN, Warszawa.

Schnittler M. \& Günther K. F. 1999. Central European vascular plant requiring priority conservation measures - an analysis from national Red Lists and distribution maps. Biodiv. Conserv. 8: 891-925.

Szafer W., Kulczyński S. \& Pawłowski B. 1988. Rośliny polskie. xxxi+1020 pp. PWN Warszawa.

Szlachetko D. 2001. Flora Polski. Storczyki. 168 pp. Multico Oficyna Wydawnicza, Warszawa.

TER BraAk C. J. F. \& ŠS Milauer P. 2002. CANOCO reference manual and CanoDraw for Windows user's guide: software for canonical community ordination (version 4.5). Ithaca, New York, US: Microcomputer Power.

URBAN D. 2013. Characteristics of locality of Liparis loeselii (L.) Rich. On Chełm Hills (West Polesie). Teka Kom. Ochr. Kszt. Środ. Przyr. 10: 455-461.
Vanden Broeck A., Van Landuyt W., Cox K., De Bruyn L., Gyselings R., Oostermeijer G., Valentin B., Bozid G., Dolinar B., Illyés Z. \& Mergeay J. 2014. High levels of gene flow may blur ecotypic divergence in a rare terrestrial orchid. BMC Ecol. 14: 20.

Wheeler B. D., Lambley P. W. \& Geeson J. 1998. Liparis loeselii (L.) Rich. in eastern England: constraints on distribution and population development. Bot. J. Linn. Soc. 126: 141-158.

ZARZYCKI K. \& SZELĄG Z. 2006. Red list of the vascular plants in Poland. In: Z. MireK, K. ZARZYCKI, W. WojewodA \& Z. SzeląG (eds.). Red list of plants and fungi in Poland, pp. 9-20. W. Szafer Institute of Botany, Polish Academy of Sciences, Kraków.

Zarzycki K., Trzcińska-Tacik H., Różański W., Szeląg Z., WoŁeK J. \& KorzeniaK U. 2002. Ecological indicator values of vascular plants of Poland. In: Z. MireK (ed.). Biodiversity of Poland, 2, 183 pp. W. Szafer Institute of Botany, Polish Academy of Sciences, Kraków. 